\title{
Spring Quarterly Meeting 1980
}

The Spring Quarterly Meeting was held at Broadmoor Hospital on 6 and 7 May by kind invitation of Dr. P. G. McGrath, Medical Superintendent. In the absence of the President overseas, the Vice-President, Dr P. G. McGrath, presided.

\section{Scientific Meetings}

The papers presented in the scientific meetings were as follows:

Tuesday 6 May

The Development of Broadmoor 1863-1980—Dr J. R. Hamilton

The Changing Role of Nurses in Broadmoor-Mr J. Clarke

Broadmoor's Relationship with NHS Psychiatric Hospitals-Dr K. Loucas

The Contribution of Dynamic Psychotherapy to Forensic Psychiatry and Vice Versa-Dr Murray Cox

Advances in the Psychological Assessment of Offender Patients-Mr A. Black

Trends in Length of Stay in Broadmoor-Dr. D. Tidmarsh

Wednesday 7 May

Morning Session A: Transcultural Psychiatry

A Study of the Outcome of Psychotic Illness Following Repatriation-Dr A. W. Burke

Violence: A Transcultural Perspective-Dr M. Lipsedge and Dr M. al-Yassiri

Mental Health Services and the Handicap of 'Madness' in Rural Kenya-Dr Sam Gatere

Psychopathology of Immigrants-Dr R. D. Chandrasena

Morning Session B: Psycho-social Aspects of Physical Illness

Renal Dialysis in the Home: How Families Cope-Dr Vivienne Cohen

Life Events before Accidents-Dr J. Connolly

Life Events and Appendicectomy-Dr Francis Creed

Psychiatric Aspects of Hysterectomy-Dr D. Gath

Afternoon Session A: Psychiatry in the Community A Family-Orientated Psychiatric Service to the London Borough of Barnet-Dr R.D. Scott

Attitudes and Referral Habits of General Practitioners to a Local Area Service-Dr T. L. Dunn

Behavioural Psychotherapy in General Practice-Dr Helena Waters
Afternoon Session B: Miscellaneous

The Development of Mental Illness Services: the Role of the Health Advisory Service—Dr D. H. Dick

Determinants of Suicide Mortality Rates: An Analysis of One Hundred Years' Data-Dr R. D. T. Farmer Suicide by Burning: A Contemporary Epidemic-Dr John Ashton

On the afternoon of 6 May, Sir Leon Radzinowicz delivered the First Peter Scott Memorial Lecture on 'Crime and Politics'. Professor John Gunn proposed the Vote of Thanks.

Throughout the day on 7 May members of the staff at Broadmoor conducted groups of College visitors on tours of the hospital.

\section{Business Meeting}

The Business Meeting was held on Wednesday 7 May.

\section{Minutes}

The Minutes of the previous meeting held on 5 and 6 February, 1980 in Sheffield (Bulletin,April 1980) were approved and signed as a correct record.

\section{OBITUARY}

The Registrar announced with regret the death of the following members:

Elizabeth Paterson Easton, Consultant Psychiatrist, St George's Hospital, Morpeth, Northumberland.

Carmencita Elliot, 2 Arum Road, Heatherlands, George, Cape Province, South Africa.

Alfred Model, Consultant Physician, Youth Counselling Clinic, Kingston and Richmond AHA.

Elizabeth Sarah Morgan, Senior Registrar. Child Psychiatry Department, The Middlesex Hospital, London.

Astor Balfour Sclare, Consultant Psychiatrist, Duke Street Hospital, Glasgow.

\section{REGISTRAR'S REPORT}

DR GERALD TimbURY presented the Registrar's report:

'Council met on 21 March and the Court of Electors on 11 February and 14 April. The Executive and Finance Committee met on 15 February, 14 March and 18 April.

Professor Pond has been re-elected to the Presidency for the year 1980-81.

The special committee collecting opinions from Divisons 
and Sections on 'Patients First' has completed its work and comments have been submitted to the DHSS. The report of the working group on Organizational and Management Problems of Mental Illness Hospitals is being studied by the Public Policy Committee. Preliminary comments will be made to the DHSS at our annual informal discussion with Departmental officials which was held this year on 25 July. [A brief summary will be appearing in the Bulletin shortly]. A discussion paper on Medical Manpower in the psychiatric specialties prepared by the Manpower Committee is being circulated to Divisions and Sections for comment. College comments have also been submitted on the report of the Blennerhassett Committee on Drinking and Driving.

The Court of Electors has given preliminary consideration to draft comments on a possible future College Diploma in Psychiatry and on training in general practice for psychiatrists. These documents, when further revised, will be circulated within the College for wide discussion.

Council has agreed to publication of the report of a joint working party on Ethical Guidelines for Behaviour Modification Programmes which was chaired by Professor O. L. Zangwill. The working party had representatives of the College, the British Psychological Society and the Royal College of Nursing.

A draft memorandum entitled Ethical Considerations of Electroplexy prepared by the joint ethical working party was discussed by Council. After careful consideration Council decided not to publish the memorandum at this stage, but it was agreed that the new Memorandum and the 1977 College Guidelines on ECT would be reviewed when the results of the current ECT research project were available. In view of correspondence in the medical and national press Council discussed whether a statement on the use of unmodified ECT should be published but decided that there was no need to add to the President's statements in the medical press.

A new edition of the Handbook for Inceptors and

\section{Correspondence}

\section{'Trahison des cleres'}

DeAR SiR

I have heard recently some senior psychiatrists refer to mental hospitals as 'bins'. There may be others who do so. They should stop it, at once.

It is offensively derogatory and unfair. The bulk of the inpatient care and treatment of the psychiatrically ill is carried out in the mental hospitals. They have a great tradition and most are admirable. They are as essential to psychiatry as are the general hospitals to medicine and surgery. That a few have been the loci of scandals may in part be attributed to the dismissive attitudes of those who, as a result of artificial
Trainees is in press and should be available soon. [Now available.]

Council has agreed to increase our contribution to the World Psychiatric Association to 2 dollars per head for Members and Fellows of the College resident in the United Kingdom.

Arrangements are in hand for members and subscribers in North America to receive their Journal more quickly by using air freight to New York. The possibility of making similar arrangements for India and the Far East is being investigated.

Work has started on the modernization of the basement premises at 17 Belgrave Square, and it is hoped that this will be completed by the end of this year. It will be followed by redecoration and renovation of the main entrance hall and staircase. The new accommodation will provide two lecture rooms, improved catering facilities, additional offices and staff room.

During the last few months a number of College staff have, unfortunately, suffered ill health, and a great deal of work has fallen on remaining staff members. College members are extremely grateful to all our staff for their loyalty and hard work. Arrangements are in hand to make certain additional appointments.

Finally the College's thanks are due to Dr McGrath and all the staff at Broadmoor Hospital whose very special efforts have resulted in an outstandingly successful meeting. The medical staff, the patients, the administration, the catering staff and volunteers, and the Friends of the Hospital have worked very hard and we are most grateful to them all for such a happy meeting.

DR McGRATH thanked Dr Timbury for his kind words and expressed the pleasure of all at Broadmoor at having been able to welcome members of the College, including some from overseas who had attended. boundaries of clinical responsibilities, have no part to play in them.

The anti-psychiatry movement is vocal and aggressively led. The public is uncertain what to think about psychiatric provisions and psychiatric treatment. Recruitment to the specialty has fallen off. The care of the aged is placing an ever-increasing burden on hard-pressed staffs. It is a trahison des clercs so to denigrate the institutions of one's specialty and work of one's colleagues, and especially so at a time of such very considerable difficulty.

Ninewells Hospital

Dundee, DDI $9 S Y$.
I. R.C. BATCheloR

Professor of Psychiatry 